\title{
Analysis of Efl Learners' Competence in Using Anaphora Reference in Reading Technical Text
}

\author{
Maspufah \\ Akademi Bahasa Asing Persada Bunda Pekanbaru \\ Email: maspufah@persadabunda.ac.id
}

\begin{abstract}
Reading is one of four basic skills which should be mastered by English majoring students. They are demanded to be able to gain information all kinds of texts well since their learning material and references were taken from English written book. In fact students had problem with motivation, limited vocabulary, and background knowledge. This research is a descriptive research. The purpose of the research was to find out the students' competence in using reference in reading technical text. The subject of the research was thirteen students of fourth semester of 2017/2018 ABA Persada Bunda Pekanbaru. The instrument used to collect the data was reading test in the form of multiple choice tests. The result were analyzed to find out the level of students' competence in using reference in technical text. From the finding, it was found that: (1) The students' competence in using personal reference in thechnical text was in good category. They had problems with motivation and lack of background knowledge in mastering personal reference (2) the students' competence in using demonstratives reference in narrative texts was in good category. The problems occurred because they had limited vocabulary and lack of motivation. Thus, it can be concluded that the students' competence in using reference in technical text still needed to be improved because they still had limited vocabulary and lack of motivation.
\end{abstract}

Keywords : Competence, Anaphora Reference, Technical Text 


\section{INTRODUCTION}

Reading is one of four basic skills which should be mastered by English majoring students. They are demanded to have a good skill in reading since their learning material and references were taken from English written text. If they are able to gain the information well, they will be easy to follow the lecture well. But if they are lack ability to do it, they will fail or get difficulties during their study.

Due to the needs of reading skills for students, Akademi Bahasa Asing (ABA) Persada Bunda put reading skills into five semester, namely Reading I, II, III, Critical Reading, and Advance Reading. During the period of the study, many kinds of text taught to increase their skill. One of them is technical text. Technical text is a text that designed specifically for a specific cereer (Maspufah:2016). The text contain scientific term which sometimes different with the general English (Halliday, 1985:124). Further, he said that technical texts had five characteristics which make it different with other text. They were objective, impersonal, technical, practical /abstract, and written language, which made technical text regarded as the most difficult text to understand.

Technical text are commonly found in English proficiency test such as Test of English as a Foreign Language (TOEFL). Many kinds of technical text from various field used in the test. Due to its crowded information, the understanding of reference may help students to pass the test. Reference is a term for the association of a word or expression with the object it refers to (Fromkin, Rodman, and Hymes, 2011:194). Then, Yule (2003:204) reference is the relationship of reference is taken to hold between expression in a text and entities in the world, and reference between expressions in different parts of a text. From their statements, it can be inferred that reference is words or phrase which should be related to its entity to get their meaning.

Based on its position in the text, Halliday and Hasan (2011:33) and Cutting (2002: 9) reference into anaphora and cataphora. Anaphora reference refers back to the text for its interpretation. Furthermore, Halliday and Hasan (2011:34) also classified anaphora reference into three types: personal reference, demonstrative reference, and comparatives reference. Anaphora reference is commonly used in technical text.

However, most of students got low score in reading, especially the technical text. This condition lead by several problems. First, since the technical text is designed for native speaker, the vocabulary size is high. It means that the vocabulary used contained many difficult words. In facing this conditions, students usually used dictionary. Looking up dictionary is ineffective way since it retards the flow of comprehension on student's 
mind (Robinson, 1975 cited in Maspufah, 2017). Looking up dictionary took a longer time and make students bored. That is why, most of students lack of motivation in reading this kind of text

Second, students confuse with the meaning scientific vocabulary where the terms used have differerent meaning with general english. While, one characteristics of technical text was technicality. For example: "I need a saw to cut the bark". In the sentence, the word saw and bark do not translated as General English terms which the word saw has the meaning as the past tense of the word see and the word bark as the sharp explosive cry of certain animals, especially a dog, fox, or seal, but, technically the word saw translated as a a hand tool for cutting wood or other materials, typically with a long, thin serrated steel blade and operated using a backward and forward movement. And the word bark translated as the skin that covers the trunk of a tree.

Based on the previous reasons, it is neessary to conduct a research entittled 'Analysis of EFL students Competence in Using Anaphora Referene in Reading Technical Text". Anaphora reference was chosen because it more frequently appear in the text. Technical text was selected as it was frequently used in English standardized test such as TOEFL.

Based on the previous explanation, the purposes of the research were formulated:

1. To find out the students' competence in using anaphoa reference in reading technical text

2. To find out the difficulties faced by EFL learners in using reference in technical text.

\section{METHOD}

This study was descriptive research. It was intended to find out the students' competence in using personal reference in technical text. Best (2005: 25) said that descriptive research describes the situation or thing that exists at the same time of the study. It means that this research dis not tend to find a new theory but only verify and describe the existing one. By implementing quantitative approach, it attempt to find out the students' competence in using anaphora reference in technical text.

This research was conducted at ABA Persada Bunda Pekanbaru, Jalan Diponegoro number 42 Pekanbaru. The population of this research was the fourth semester semester students of 2017/ 2018 of ABA Persada Bunda. The sample was 13 students. Arikunto (2010:112) stated that if the population is less than 100, the sample will be all population number. So, all the students were taken as the sample.

There were two instruments used in this research: quantitative and qualitative instrument. The quantitative instrument in the form of test and the qualitative instrument in the form of interview. In collecting the data, the 
reading tests were administered. After the students' answer were scored, interview was conducted to them who got low score in interpreting each type of deixis.

The quantitative data were analyzed by scoring the test, determining the standard of competence based on their minimum achievement criteria that was 80 , counting the mean score. then compared with the standard of level competence in order to determine the level of students' competence in interpreting deixis in narrative text. The qualitative data were analyzed by reducing the data, displaying the table, and drawing a conclusion.

\section{FINDING AND DISCUSSION}

Based on the findings, discussion was presented as the following description.

\section{Students' Competence in Personal Anaphora Reference}

The students' competence in using reference in technical text was in good category. Their average score was 75 . Thus, it was unsufficient with the minimum score which had been determined before, 80. Their level of competence can be seen in the following table.

\begin{tabular}{|c|c|c|c|}
\hline Score & $\begin{array}{c}\text { Number } \\
\text { of } \\
\text { Student }\end{array}$ & Percentage & Category \\
\hline $\begin{array}{c}80- \\
100\end{array}$ & 6 & $46 \%$ & Excellent \\
\hline $66-79$ & 6 & $46 \%$ & Good \\
\hline $40-65$ & 1 & $8 \%$ & Fair \\
\hline$<39$ & - & - & Poor \\
\hline
\end{tabular}

Some students got problem in using personal anaphora reference which its interpretation did not state directly in the choice, but it was also in referent form. They were confused and tend to do the mistake because they did not have enough courage or effort to find the answer. In other words, they tend to have lack motivation in reading comprehension. This condition could be caused by limited vocabulary understanding. In this case, the lecturers should provide more various technique and exercise to expand their students' vocabulary size. While in technical text, which mostly occurred in TOEFL which had high size of vocabulary, condensed information, and coded in different kinds of writing (Halliday,1985:124).

For example :

(1) Text : "Carnivorous plants such as the sundew and the Venus Flytrap are generally found in humid areas where there is an inadequate supply of nitrogen in the soil. In order to survive, these plants have developed mechanism to trap insects within their foliage. They have digestive fluids to obtain necessary nitrogen from the insects." 
Question: The pronoun they refer to...........
a. Humid areas
c. These plants
b. Insects
d. digestive fluids

Some students were incorrect to find the reference of personal reference which its interpretation stated do not clearly in the text. They could not find the entity and then they tend to interpret it lexically. Based on the interview, they said that did not understand the text as it had crowded examples. They also lack of background knowledge about some terms in economic and the information presented in the text. So, they could not sense the text and relate it in real situation, especially about the economic

For example:

(2) Text: 'It's averages are composed of four different types of averages: the average stock of thirty industrial firms, the average price of the common stock prices of twenty transportation companies, the common stock prices of fifteen utility companies, and an overall average of all the sixty- five stock used is industrial average. It is often used by an investor interested in checking the state of the stock market before making investment in an industrial stock".

Question: The pronoun "it" refers to.
a. The industrial average
b. The state of the stock market
c. The Dow Jones average
d. An investment

\section{Students' Competence in Using Demonstrative Reference}

The students' competence in using demonstrative reference was in good. It can be seen that their average score was 78 but still insufficient with the minimum achievement criteria 80 . Their level of competence can be seen in the following table.

\begin{tabular}{|c|c|c|c|}
\hline Score & $\begin{array}{c}\text { Number of } \\
\text { Student }\end{array}$ & Percentage & Category \\
\hline $88-100$ & 7 & $54 \%$ & Excellent \\
\hline $66-79$ & 1 & $8 \%$ & Good \\
\hline $40-65$ & 5 & $38 \%$ & Fair \\
\hline$<39$ & - & - & Poor \\
\hline
\end{tabular}

Some student had limited vocabulary which made them could not find the referent word. Limited vocabulary also made some students were confuse to find demonstrative reference which its' interpretation should be related to the previous information to get the clue. Without sufficient vocabulary, the students showed inability to use linguistics cues in the large context to draw meaning and recognize lexical relationship and meaning relationship between sentences (Alderson, 2000:56).

For example:

(3) Text : "Mardi Gras, which means "Fat Tuesday" in French, was introduced to American by French colonists in the early eighteenth century. From that time it has grown in popularity, particularly in New Orleans, and today it is 
actually a legal holiday in several southern states.

Question : The pronoun "that" in line 2 refers to...

a. Mardi Gras day

b. Today

c. Tuesday

d. Eighteen century

The demostrative reference which only consist of indicating this, that, and also its pluralism made students confuse. They tend to see the meaning of demonstrative reference lexically and forget what actually the word "this" or "that" referred to

For example;

(3) Text : "Parades, parties, balls, an numerous festivies take place throughout the week before Mardi Gras Day; tourists from various countries throughout the world flock to New Orleans for the celebration where they take part in a week of these activities before returning home for some muchneeded rest.

Question : The pronoun "these" in line 8 refers to....

a. Numerous festivities

c. Tourists

b. Various countries

d. countries

Generally, it can be inferred that the students' problems in using reference in technical text were because of lack of backgroundknowledge, limited vocabulary, and low motivation toward reading. Besides that, types of question given did not affect or become a problem for them.

To solve this problem lecturers are expected to explain more about types of reference to avoid confusion whenever they found referent words in a text, because a sentence may has more than one types of referent. Beside that lecturers are also expected to give more technical text in teaching learning process as it is often used in TOEFL test (Herdi, 2016). So, the students will be around with the condensed information, the size of vocabulary, and enrich their background knowledge from variousfield.

\section{CONCLUSION}

Based on the findings and discussion, it can be concluded:

1. The students' competence in using personal reference in technical text was in good category. Their average score was 75 or insufficient with the minimum scored which had been determined 80. They had problems in using personal reference in technical text because they lack of motivation and background knowledge.

2. The students' competence in using demonstrative reference in technical text was also in good category. Their average score was 75 and still insufficient with the minimum achievement criteria which had been determined 80. The problems 
occurred because they had limited vocabulary and lack of motivation.

\section{REFERENCES}

Arikunto, S. 2010. Prosedur Penelitian Suatu Pendekatan Praktek. Jakarta: Rineka Cipta.

Best. J.W. 2005. Research in Education. Englewood: Prentice Hall.

Cutting, J. 2002. Pragmatics and Discourse. London : Routledge.

Fromkin, V, Rodman, R and Hyams, N.2011 ( $9^{\text {th }}$ edition). An Introduction to Language. Boston: Michael Rosenbery.

Halliday, M.A.K (1985) Spoken and Written modes of Meaning. Ney York: Routledge . 2011. Cohesion in English. London: Longman.

Herdi, Herdi. "The Students' Reading Ability on Test of English as the Foreign Language (TOEFL)." ELT-Lectura 3.1 (2016).

Maspufah. 2015. Students' Competence in Interpreting Deixis in Narrative Text at Grade IX IPA 1 Students of SMA Dharma Loka Pekanbaru. Journal English Language Teaching, Vol 1 Nomor 1 Maret 2015

. 2016. Analysis Study on the Students' Ability in Using Reference in Narrative text. Journal of Language and
Education, Vol 1 No 2 January 2016

2017. Students' Mastery in Using Context Clue in Reading Technical Material. Journal of Language and Education, Vol 2 No 1 February 2017

Yule, G. 1996. Pragmatics. Oxford:Ox 